\title{
Competitiveness of Selected South-Eastern European Countries in European Union Wood Flooring Market
}

\section{Konkurentnost odabranih zemalja jugoistočne Europe na tržištu drvenih podova Europske unije}

\author{
Original scientific paper • Izvorni znanstveni rad \\ Received-prispjelo: 20. 10. 2019. \\ Accepted-prihvaćeno: 28. 4. 2020. \\ UDK: $630 * 7$ \\ https://doi.org/10.5552/drvind.2020.1963
}

(C) 2020 by the author(s).

Licensee Faculty of Forestry, University of Zagreb. This article is an open access article distributed under the terms and conditions of the Creative Commons Attribution (CC BY 4.0) license.

\begin{abstract}
Selected South-Eastern European countries (SEEC - Albania, Bosnia and Herzegovina, Croatia, Montenegro, North Macedonia, Serbia and Slovenia) represent significant producers and exporters of wood flooring in Europe. In 2018, 9.4\% of Europe's wood flooring production originated from this region. The region is a net exporter of wood flooring since it exports over $50 \%$ of total production. The most important market for the export of wood flooring is the European Union with a share of over $60 \%$ in total exports. Trends in this market are important for manufacturers and exporters from the region. Therefore, the analysis of the impact of the European Union imports on wood flooring production in the SEEC was conducted by application of econometric modelling. The parameters of the obtained model show that the increase of approximately $0.75 \%$ could be expected in the production of wood flooring in selected South-Eastern European countries for each precentral increase in the European Union imports. In addition to these results, the paper presents the analysis of the competitiveness of wood flooring export from the region measured by the Competitiveness Growth Index (RCA1). The aim of this analysis was to quantify the level of their price and non-price competitiveness in the European Union market. Conducted analyses show that the Competitiveness Growth Index (RCA1) had positive values (higher than one) for most significant countries from the SEEC for most of the observed period.
\end{abstract}

Key words: competitiveness; flooring; market; models; wood

SAŽETAK・Odabrane zemlje jugoistočne Europe (SEEC - Albanija, Bosna i Hercegovina, Hrvatska, Crna Gora, Sjeverna Makedonija, Srbija i Slovenija) značajni su proizvođači i izvoznici drvenih podova u Europi. U 2018. godini 9,4\% europske ponude drvenih podova proizvedeno je upravo u toj regiji. Regija je neto izvoznik drvenih podova jer izvozi više od 50 \% ukupne proizvodnje. Najvažnije je tržište za izvoz drvenih podova Europska unija,

\footnotetext{
${ }^{1}$ Author is full professor at University of Belgrade, Faculty of Forestry, Department of Wood Science and Technology, Belgrade, Republic of Serbia.

2 Authors are teaching assistants at University of Belgrade, Faculty of Forestry, Department of Wood Science and Technology, Belgrade, Republic of Serbia.

3 Author is full professor at Biotechnical Faculty, University of Ljubljana, Ljubljana, Slovenia.

${ }^{4}$ Author is PhD at Saga drvo company, Stara Pazova, Republic of Serbia.
} 
na koju otpada više od 60 \% ukupnog izvoza. Trendovi na tržištu Europske unije vrlo su važni za proizvođače $i$ izvoznike iz promatranih zemalja SEEC-a. Stoga je primjenom ekonometrijskog modeliranja analiziran utjecaj uvoza Europske unije na proizvodnju drvenih podova u SEEC regiji. Parametri dobivenog modela pokazuju da se sa svakim postotkom povećanja uvoza u Europsku uniju može očekivati rast proizvodnje drvenih podova u odabranim zemljama jugoistočne Europe za oko 0,75\%. Osim rezultata provedene analize, u radu su izneseni $i$ rezultati analize konkurentnosti izvoza drvenih podova iz zemalja SEEC-a mjereni indeksom rasta konkurentnosti (RCA1). Cilj analize bio je kvantificiranje razine njihove cjenovne i necjenovne konkurentnosti na tržištu Europske unije. Provedene analize pokazuju da je indeks rasta konkurentnosti (RCA1) za najznačajnije zemlje SEEC-a u većini godina promatranog razdoblja imao pozitivne vrijednosti (veće od 1).

Ključne riječi: konkurentnost; podovi; tržište; modeli; drvo

\section{INTRODUCTION} 1. UVOD

Analysis of the market situation, trends and competitiveness are the subjects of interest to scientists and professionals dealing with wood industry. This is due to the stochastic character of the market development, whose intensity of changing is largely determined by the market positions of companies and countries on the regional and world markets. Therefore, the results of market research are a subject of interest to business sector, strategy makers and decision makers in companies and institutions. Research linkages and cause-effect relationships between different phenomena on the market are among the key elements of the market research in the field of wood industry.

According to Dzian et al. (2018), modelling of the market was researched on many different scientific platforms. In their papers, Gravelsins et al. (2017) used the system of dynamics modelling to determine the added value for different wood products. Within their econometric market analysis, Toppinen et al. (2010) studied the following elements: 1) modelling of product demand and supply, 2) price analysis and testing of market integration, 3) market demand and price forecasting, 4) modelling industry location and 5) production technology and factor demand for wood based products.

Appropriate indices are generally used for the analysis of competitiveness in the wood processing industry. In such a way, Paluš et al. (2015) analysed the trade performance and competitiveness of the Slovak wood processing industry and compared them with the Visegrad group countries. They used a set of trade performance and competitiveness indicators for analysing the position and changes in competitiveness of the respective countries, as followed: Trade Specialisation Index, Export/Import Ratio, Standard Grubel-Lloyd Index, Revealed Comparative Advantage and Vollrath's Revealed Competitive Advantage Indices.

For analysing the competitiveness of wood and semi-finished wood products of Slovakia, Parobek et al. (2016) used the Revealed Comparative Advantage $(R C A)$ index and the Comparative Price Level $(C P L)$ index.

Most of the above-mentioned examples were confirmed by Hetemäki et al. (2016), who stated in their work that comprehensive market analyses related to the trends in the global forest products industry came in surprisingly short supply. The forest products market long-term outlook studies are rarely published in scientific journals. They tend to be published regularly by consulting companies and international organizations or commissioned by governments. Otherwise, research on the forest industry market outlook takes place less systematically and typically focuses on one particular product category or region.

When it comes to the competitiveness of wood products produced in the SEEC (South-Eastern European countries, alphabetically: Albania, Bosnia and Herzegovina, Croatia, Montenegro, North Macedonia, Serbia and Slovenia), there are not many published papers. Based on the analysis of the competitiveness of the Serbian wood and furniture industry, Glavonjić et al. (2016) concluded that the value of the current wood products exported from Serbia to certain markets was symbolic compared to the overall turnover of these products at specific markets. In order to change that, one of the conditions is to increase the degree of finalisation of wood raw material available in Serbia.

Considering the above-mentioned, there is a need to use relevant scientific and statistical tools to obtain reliable answers to various market questions important to decision-makers. This paper presents the impact of the EU imports on the production of wood flooring in the SEEC. Wood flooring is one of the hallmark wood products by which the SEEC are recognised in Europe and beyond.

The main aim of the research is to examine the relationships and draw conclusions about the cause and effect relationships between the import of wood flooring in the EU countries and their production in the SEEC. In addition, the specific goal of the research is to analyse the price and non-price competitiveness of the wooden flooring that is exported from this region.

\section{MATERIALS AND METHODS}

\section{MATERIJALI I METODE}

The material required for the analysis in this paper comprehends data and outputs from relevant primary and secondary sources related to the competitiveness of products, industries and countries, as well as data obtained from relevant statistical databases. The most important primary data sources were the wood flooring companies, while the secondary sources were statistical databases on trade of wood products from countries in the region as well as international data- 
Table 1 Set of variables used in models

Tablica 1. Varijable primijenjene u modelu

\begin{tabular}{|c|l|c|l|}
\hline ID & \multicolumn{1}{|c|}{ Variable / Varijabla } & $\begin{array}{c}\text { Unit } \\
\text { Mjera }\end{array}$ & \multicolumn{1}{c|}{ Source / Izvor } \\
\hline PRD & Production / proizvodnja & $\mathrm{m}^{2}$ & $\begin{array}{l}\text { EUROSTAT; Statistical offices of selected countries (SEEC); University of } \\
\text { Belgrade-Faculty of Forestry }\end{array}$ \\
\hline IMP & Import / uvoz & $\mathrm{m}^{2}$ & EUROSTAT \\
\hline
\end{tabular}

bases (EUROSTAT, FAO, and UNECE). Available scientific papers, studies and analyses were used as additional secondary data sources.

Analytical-synthetic methods were used for the purpose of data collection, systematization and processing. Statistica 7.0 software package was used for econometric modelling, in which correlation and regression are combined into a single methodological tool. Evaluation of parameters in econometric models was performed on the basis of the methodological guidance developed by Ranković (1996) and Jovičić (2018). Out of the general scientific methods, the hypothetical-deductive method was chosen and applied. Table 1 shows the name of the variables chosen for the econometric modelling, their symbols and measuring units.

The Competitiveness Growth Index (RCAl) was used to analyse the competitiveness of export of wooden flooring. The choice of this indicator is a result of the fact that the competitiveness of only one product group (wood flooring) is considered, and not the competitiveness of the industry. Therefore, the analysis based on the value of this selected index is sufficient to assess the competitiveness of this product group. The following indexes: Revealed comparative advantage $R C A$; Index of net business performance $-R C A 2$; Index of contribution to the trade balance - CTB; GrubelLloyd index - GLI, Michaely index - MI are usually used to measure the competitiveness of industries and countries.

In that sense, Index of Competitiveness Growth (RCA1) is calculated as follows (Milićević et al. 2017):

Where:

$$
R C A l=\frac{\frac{X_{\mathrm{ij}}}{X_{\mathrm{j}}}}{\frac{X_{\mathrm{i}}}{X}}
$$

$X_{\mathrm{ij}}$ - export value of commodity group , ,i“ within industry,,$i^{\prime \prime}$ in country,$i{ }^{\prime \prime}$

$X_{\mathrm{j}}$ - value of total export from country,,$j$ "

$X_{\mathrm{i}}$ - world export of commodity group ,,$i^{\text {“ }}$

$X$ - total world export

If $R C A 1>1$, there is comparative advantage of industry in the worldwide market. If $R C A 1<1 \mathrm{a}$, commodity group has no competitive ability in the relevant market.

The fact is that there is not only one indicator that can comprehensively measure competitiveness. Some indicators are only applicable to the level of the overall economy. Others are applicable at the industry level, and some of them can be used to measure competitiveness at lower levels of economic structure (Bobáková and Hečková, 2007). Considering the fact that the pa- per investigates the competitiveness of only one product group as well as the complexity of indicators that measure competitiveness at higher levels of economy, it can be concluded that the choice of Index of Competitiveness Growth $(R C A 1)$ is a sufficiently reliable and comprehensive indicator for that product group, able to fulfil the aim of the research.

\section{RESULTS}

\section{REZULTATI}

The results contain the following segments: Wood flooring market in Europe including the SEEC; Impact of the EU imports on development of wood flooring production in the South-Eastern European countries: the econometric model; and Assessment of the competitiveness of exports of wood flooring from the SEEC.

\subsection{Wood flooring market in Europe}

3.1. Tržište drvenih podova u Europi

The analysis of data on wood flooring production and consumption in Europe shows that the market has not yet recovered after the global economic crisis. Production and consumption in 2018 are still below the 2007 values. In terms of consumption, it reached the level of 93.5 million $\mathrm{m}^{2}$ in 2018, which is 3.9 million $\mathrm{m}^{2}$ less than the maximum level reached in 2009. Norway (about one million $\mathrm{m}^{2}$ ) and FEP (European Federation of the Parquet Industry) members (about 7.2 million $\mathrm{m}^{2}$ ) have recorded the largest drop in consumption in the last ten years. On the other hand, consumption growth of 0.42 million $\mathrm{m}^{2}$ and 1.26 million $\mathrm{m}^{2}$, respectively, has been recorded in Switzerland and the SEEC. Despite the fall in consumption, the European Union remains the largest market for the consumption of wood flooring in Europe (without Russian Federation), with a share of $86 \%$ in 2018 (Figure 1, sources: University of Belgrade Faculty of Forestry, Timber Trade Centre database (internal); FEP, 2019). Observed by countries, the largest consumers of wood flooring in Europe are Germany, Italy, France, Sweden, Austria and Switzerland (FEP - European Federation of the Parquet Industry, 2019).

The SEEC increased their consumption of wood flooring from 2.82 million $\mathrm{m}^{2}$ in 2009 to 4.08 million $\mathrm{m}^{2}$ in 2018 (source: University of Belgrade Faculty of Forestry, Timber Trade Centre database (internal)). Consequently, their share in the total European consumption of wood flooring has increased from $2.9 \%$ in 2009 to $4 \%$ in 2018. The highest consumption growth was recorded in Croatia, Bosnia and Herzegovina and Serbia. 


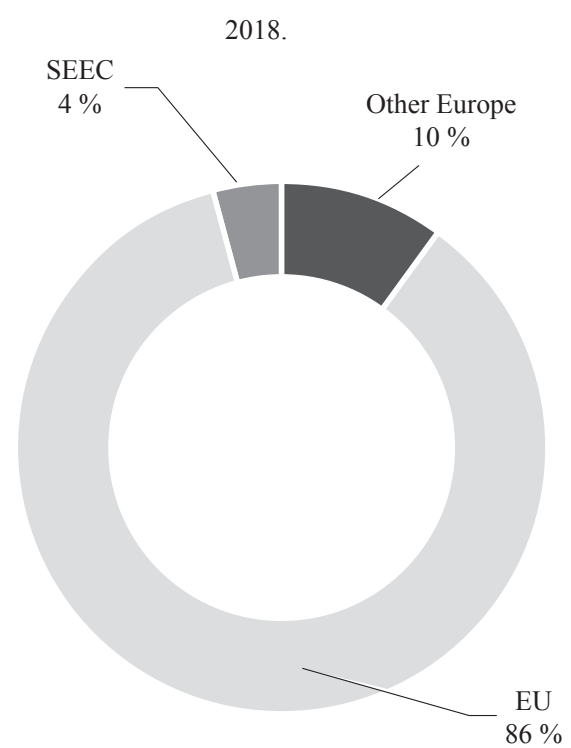

Figure 1 Share of selected regional groups in total consumption of wood flooring in Europe

Slika 1. Udio pojedinih regionalnih grupacija u ukupnoj potrošnji drvenih podova u Europi

The total production of wood flooring in the SEEC in 2018 amounted to 8.48 million $\mathrm{m}^{2}$, representing $9.4 \%$ of production in Europe. In the structure of production and consequently consumption, multilayer floors come in the first place, followed by classic and mosaic parquet. This structure of production is very similar to the structure of production in Europe. According to the FEP report for 2018 (source: FEP, 2019), multilayer flooring accounted for $82 \%$ of the total production of this association, while classic and mosaic parquet accounted for $17 \%$ and $1 \%$, respectively. In Serbia in 2018, the share of multilayer flooring was 78 $\%$, classic parquet $20 \%$, and solid flooring $2 \%$ (source: University of Belgrade Faculty of Forestry, Timber Trade Centre database (internal)).

The dominant share of multilayer flooring in the structure of total production has greatly influenced its value. In 2018, the total value of wood flooring production in Europe was approximately $€ 1.9$ billion or 21.1 $€ / \mathrm{m}^{2}$. Finland and Italy were the two leading countries in Europe in terms of output value per $1 \mathrm{~m}^{2}$, with 55.8 $€ / \mathrm{m}^{2}$ and $47.2 € / \mathrm{m}^{2}$, respectively. Poland and Slovakia had the lowest value of this indicator and it was below $10 € / \mathrm{m}^{2}$ (source: Eurostat, 2019). In terms of the SEEC, Croatia had the highest value amounting to $18 € / \mathrm{m}^{2}$, followed by Slovenia with $17.8 € / \mathrm{m}^{2}$ and Serbia with $17.4 € / \mathrm{m}^{2}$. Compared to the average value of this indicator for Europe, all three countries were below the European average. Northern Macedonia $\left(9.7 € / \mathrm{m}^{2}\right)$ and Albania $\left(10.6 € / \mathrm{m}^{2}\right)$ had the lowest values of this indicator (sources: Croatian Bureau of Statistics, 2019; Statistical office of the Republic of Serbia, 2019; Statistical office of the Republic of Slovenia, 2019; Monstat, 2019; State Statistical office of the Republic of North Macedonia, 2019; Institute of Statistics of Albania, 2019; The Agency for statistics of Bosnia and Herzegovina, 2019).
Oak has been the most popular wood species in the consumption of wood flooring in Europe for several decades. According to the FEP report for 2018, the share of oak in the total consumption of wood flooring in this association was $80.3 \%$, while all other wood species shared the remaining $19.7 \%$. Ash accounted for $6.8 \%$, tropical species $3.7 \%$, beech $2.2 \%$ and walnuts $1.3 \%$, while the share of other species was about or below $1 \%$ (source: FEP, 2019).

Compared to the production, the consumption of wood flooring in Europe in 2018 was higher by approximately 3.4 million $\mathrm{m}^{2}$, which means that the missing amount was settled from imports. Europe is a major exporter but also a major importer of wood flooring and is, therefore, an important market for many countries. This is especially true for the European Union, which is the main market for the export of wood flooring from the SEEC.

Imports of wood flooring in the European Union have been growing over the last ten years at the average annual rate of $3.6 \%$. In quantitative terms, imports of wood flooring in the EU increased from 56.9 million $\mathrm{m}^{2}$ in 2009 to 78.7 million $\mathrm{m}^{2}$ in 2018 , or about 21.8 million $\mathrm{m}^{2}$, which confirms the previous finding on the size of this market.

The analysis of foreign trade flows for 2018 showed that $64 \%$ of total exports of wood flooring from the SEEC were placed in the European Union market. Among other regions, the Russian Federation was significant with a share of $19 \%$, while the share of all other countries was only $17 \%$ (Figure 2, sources: Croatian Bureau of Statistics, 2019; Statistical office of the Republic of Serbia, 2019; Statistical office of the Republic of Slovenia, 2019; Monstat, 2019; State Statistical office of the Republic of North Macedonia, 2019; Institute of Statistics of Albania, 2019; The Agency for statistics of Bosnia and Herzegovina, 2019).

Having in mind the importance of the EU market for the export of wood flooring from the SEEC, the results of econometric modelling of the impact of the EU imports on the development of production of wood

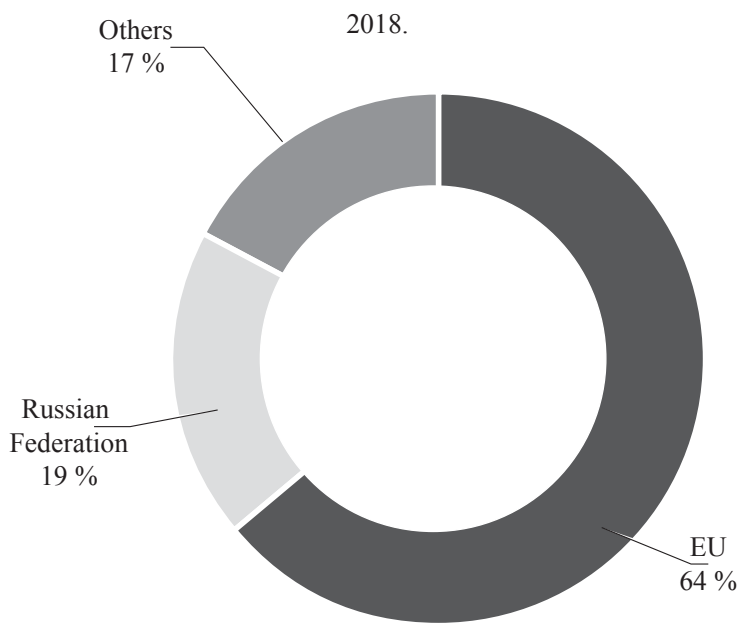

Figure 2 The main export destinations of wooden flooring from selected South-Eastern European countries Slika 2. Glavna odredišta izvoza drvenih podova iz promatranih zemalja jugoistočne Europe 
flooring in the SEEC are presented below in order to consider the cause and effect relationships between these two economic variables.

3.2 Impact of EU imports on development of wood flooring production in selected SouthEastern European countries - econometric model

3.2. Utjecaj uvoza EU-a na razvoj proizvodnje drvenih podova u promatranim zemljama jugoistočne Europe - ekonometrijski model

The impact of the EU imports on production of wood flooring in the SEEC is best illustrated by its degree of form in the simple regression model. The basic parameters of this regression model are presented in Table 2.

The coefficient of determination shows that $71 \%$ of variations in wood flooring production in the SEEC are explained by the model. The high correlation coefficient, its significance at a given level of significance as well as the precisely estimated parameter $b$ (t-test) show the strong impact of the EU imports on the production of wood flooring in the SEEC. In this case, it can be expected that for each percentage increase of the EU imports, the production of wood flooring in the SEEC could increase by approximately $0.75 \%$.

\subsection{Assessment of competitiveness of wood flooring export from selected South-Eastern European countries}

3.3. Ocjena konkurentnosti izvoza drvenih podova iz promatranih zemalja jugoistočne Europe

The competitiveness of exporting a product from a country can be assessed in several ways. One of the more accurate ways of assessing competitiveness is to measure competitiveness by using appropriate indexes. For the purpose of this paper, the Competitiveness Growth Index $(R C A 1)$ was selected as an indicator whose values best represent the state of the competi-
Table 2 Model results

Tablica 2. Rezultati modela

\begin{tabular}{|c|c|c|}
\hline $\begin{array}{l}\text { Model } \\
\text { Model }\end{array}$ & $\begin{array}{l}\text { Constant } \\
\text { Konstanta }\end{array}$ & $\begin{array}{c}\text { Import } \\
U \underline{\underline{v O Z}}\end{array}$ \\
\hline PRD (y) & 2.3666 & 0.74774 \\
\hline St. error & 3.06859 & 0.1705 \\
\hline$t$-test & 0.77123 & 4.3838 \\
\hline $\mid t$-test $\mid$ & $\left|t_{\mathrm{a}}\right|<t_{005}$ & $\left|t_{\mathrm{b}}\right|>t_{005}$ \\
\hline \multicolumn{3}{|c|}{$\begin{array}{l}\text { Statistical characteristic } \\
\text { Statističke karakteristike }\end{array}$} \\
\hline $\mathrm{R}$ & $R^{2}$ & $R^{2}$ cor \\
\hline 0.84 & 0.71 & 0.67 \\
\hline$F(1,8)$ & $S_{\mathrm{e}}$ & $D W(+)$ \\
\hline 19.218 & 0.05323 & 1.71467 \\
\hline
\end{tabular}

PRD - production / proizvodnja, $R$ - correlation coefficient / koeficijent korelacije, $R^{2}$ - coefficient of determination / koeficijent determinacije, St. error - standard error / standardna pogreška, DW - Durbin-Watsonova statistika, $F-F$-test, $p$ - level $(0,05) /$ razina značajnosti

tiveness of the selected product in the selected time period.

Based on the formula given in the "Materials and methods" chapter, the Competitiveness Growth Index $(R C A 1)$ for the four SEEC countries was calculated and shown in Table 3 (sources: Croatian Bureau of Statistics, 2019; Statistical office of the Republic of Serbia, 2019; Statistical office of the Republic of Slovenia, 2019; The Agency for statistics of Bosnia and Herzegovina, 2019). In the remaining three countries (Albania, Montenegro and Northern Macedonia), the share of wood flooring export is symbolic, with their exports being mostly directed to the surrounding countries.

The Competitiveness Growth Index $(R C A 1)$ has positive values (higher than one) for all selected countries from SEEC region for most of the observed period. This shows the high competitiveness of wood

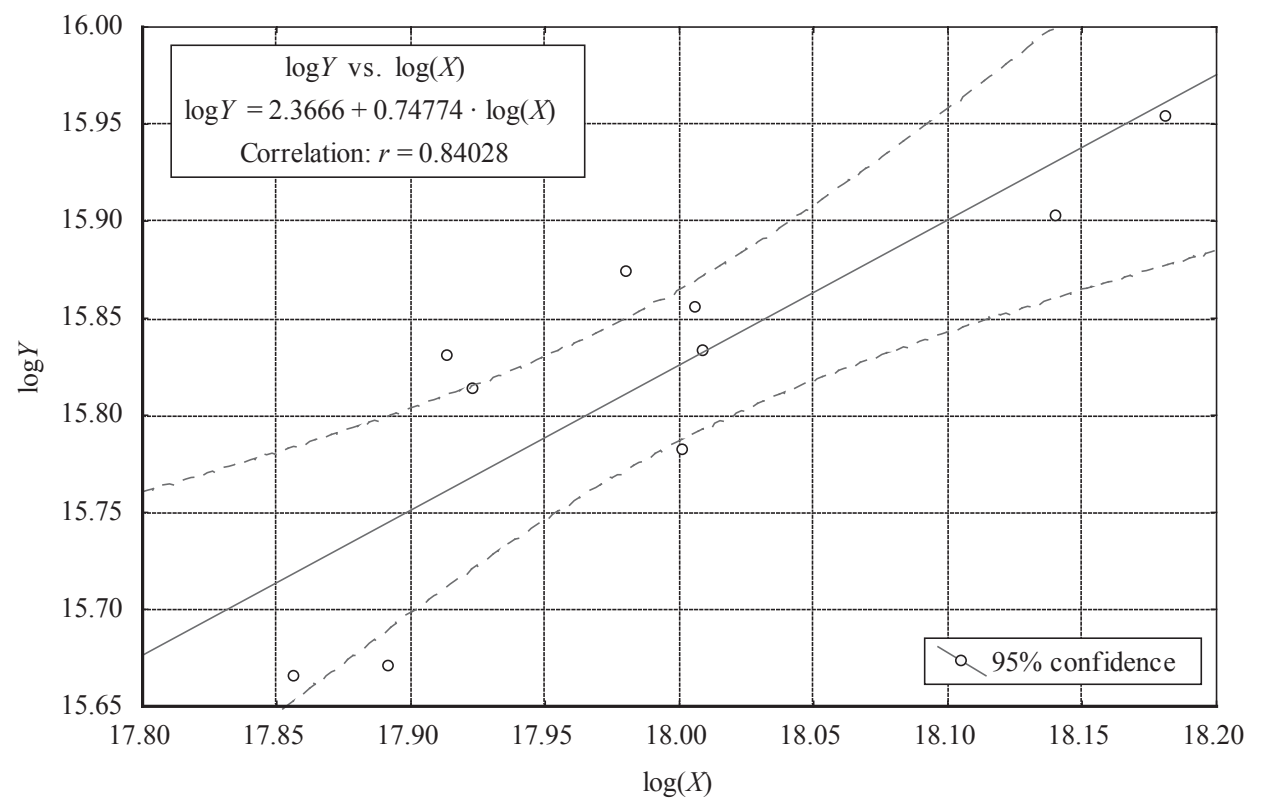

Figure 3 Impact of EU imports on wood flooring production in selected South-Eastern European countries: econometric model

Slika 3. Utjecaj uvoza EU-a na proizvodnju drvenih podova u promatranim zemljama jugoistočne Europe - ekonometrijski model 
Table 3 Competitiveness Growth Index (RCA1) values for the export of wood flooring from four most significant SEEC countries

Tablica 3. Vrijednosti indeksa rasta konkurentnosti izvoza drvenih podova za četiri najznačajnije zemlje iz SEEC regije

\begin{tabular}{|l|c|c|c|c|c|c|c|c|c|c|}
\hline & $\mathbf{2 0 0 9}$ & $\mathbf{2 0 1 0}$ & $\mathbf{2 0 1 1}$ & $\mathbf{2 0 1 2}$ & $\mathbf{2 0 1 3}$ & $\mathbf{2 0 1 4}$ & $\mathbf{2 0 1 5}$ & $\mathbf{2 0 1 6}$ & $\mathbf{2 0 1 7}$ & $\mathbf{2 0 1 8}$ \\
\hline $\begin{array}{l}\text { Bosnia and Herzegovina } \\
\text { Bosna i Hercegovina }\end{array}$ & 0.40 & 1.35 & 6.67 & 8.93 & 8.74 & 10.53 & 10.05 & 10.87 & 9.98 & 7.91 \\
\hline Croatia / Hrvatska & 15.96 & 14.37 & 18.54 & 18.72 & 20.31 & 16.29 & 12.40 & 11.32 & 12.47 & 18.53 \\
\hline Serbia / Srbija & 29.88 & 35.31 & 40.34 & 40.55 & 30.25 & 25.13 & 14.81 & 10.67 & 13.10 & 12.98 \\
\hline Slovenia / Slovenija & 1.45 & 1.01 & 0.98 & 1.40 & 1.10 & 2.52 & 1.88 & 1.54 & 1.67 & 1.37 \\
\hline
\end{tabular}

Note: Author's calculations based on statistical data. / Izračunano na temelju statističkih podataka.

flooring exported from these countries to the international market, including the EU. Serbia is the leader in the region, in terms of the $R C A 1$ index value, whose average value in the observed period was 25.30 , followed by Croatia with 15.89. The other two countries, Bosnia and Herzegovina and Slovenia, had significantly lower average values of this index of 7.54 and 1.49 , respectively. Bosnia and Herzegovina had an RCA1 value of less than 1 in 2009, and Slovenia in 2011, but after those years its value increased rapidly. The largest fluctuation in the value of the $R C A 1$ index was recorded by Serbia due to the large drop in exports in 2015 and 2016. Although exports increased during 2017 and 2018 , this growth could not mitigate the fluctuations of $R C A 1$ index.

\section{DISCUSSION}

\section{RASPRAVA}

The high value of the $R C A 1$ index for Serbia and Croatia shows that the export of wood flooring is a significant item in the total exports of these countries. The average share of wood flooring exports in the total export of Serbia, in the observed period, was $0.32 \%$, and in the total export of Croatia $0.21 \%$.

The price competitiveness of wood flooring export from the SEEC to the EU market was analysed in this paper using the indicator of export value per square meter $\left(€ / \mathrm{m}^{2}\right)$. The total value of exported wood flooring from Croatia in 2018 amounted to $€ 34.8$ million or $17.2 € / \mathrm{m}^{2}$, and from Serbia to $€ 27.4$ million or $14.6 € /$ $\mathrm{m}^{2}$. Slovenia had the highest export value per unit of this product amounting to $20.2 € / \mathrm{m}^{2}$, despite the fact that its export of wood flooring was significantly lower (€ 6.7 million) compared to Serbia and Croatia. Bosnia and Herzegovina had the lowest export value per unit of this product, amounting to $11.1 € / \mathrm{m}^{2}$ (sources: Croatian Bureau of Statistics, 2019; Statistical office of the Republic of Serbia, 2019; Statistical office of the Republic of Slovenia, 2019; The Agency for statistics of Bosnia and Herzegovina, 2019).

The average import $\left(€ / \mathrm{m}^{2}\right)$ of wood flooring in first four most important EU countries for Croatian wood flooring export in 2018 , was: Italy $\left(22.3 € / \mathrm{m}^{2}\right)$, Lithuania $\left(18.0 € / \mathrm{m}^{2}\right)$, Germany $\left(18.0 € / \mathrm{m}^{2}\right)$, Austria $\left(17.4 € / \mathrm{m}^{2}\right)$. For Serbia, the average import $\left(€ / \mathrm{m}^{2}\right)$ of wood flooring in the first two most important EU countries in 2018, was: Romania $\left(14.7 € / \mathrm{m}^{2}\right)$, Bulgaria (15.6 $€ / \mathrm{m}^{2}$ ) (sources: Croatian Bureau of Statistics, 2019; Statistical office of the Republic of Serbia, 2019).
Comparative analysis of the average value of exports per unit of product from the selected countries and of the average value of imports per unit of product for the EU countries, their most significant markets, clearly shows that the average value of exports of wood flooring from the SEEC was below the average value of imports of selected EU countries. It can be concluded that the raw material used in the production of wood flooring has not yet reached the level of added value that would be desirable in its export to the EU market. Therefore, the main competitive advantages of the SEEC continue to be in the area of lower operating costs for businesses. A similar conclusion was drawn by Milićević et al. (2017) in analysing the competitiveness of the Serbian wood processing industry. They state that the establishment of long-term competitiveness in the domain of wood processing industry cannot depend on the exploitation of natural resources only, but has to be increasingly based on production and implementation of technologically complex products and services with higher value added, on the basis of intensive exploitation of natural resources (various types of wood assortment).

Export prices for solid flooring from Serbia have increased slightly over the last few years compared to the domestic sales prices. In the higher quality classes such as select and nature, there was an increase of about $10 \%$, while in the lower rustic class this increase was about $5 \%$. This was influenced by several factors, the most significant being the increase of prices of logs, especially in the purchase from private forests. In addition, on several occasions, there has been an increase of salaries and price of electricity. For example, in 2019, the price of electricity for industrial consumers in Serbia increased by about $25 \%$, which also resulted in an increase in production costs.

Considering that the current competitive advantages of producers from the SEEC cannot be the main pillars of competitiveness in the long run, innovations are needed in the production of new types of flooring with significantly greater added value in the short term.

When it comes to non-price competitive factors, wooden flooring produced and exported from the SEEC meet the market requirements in terms of quality of raw materials, precision of manufacturing, ecological components of the surface treatment, humidity, packaging, delivery time and other requirements. Most manufacturers in the region have the technology and the skills of the workforce to meet almost all market requirements related to non-price elements of the com- 
petitiveness. The main problems in their business in the last few years have been the growth of exports of the highest quality wood raw material from the region (especially logs and elements of oak, ash, maple, walnut). Therefore, the supply of raw materials for flooring has been reduced year by year. The decrease in supply has led to the increase in the prices of wood raw materials and, consequently, to the increase in the cost of production.

If this trend continues in the following years, it will have a severe negative impact on the profitability of the wood flooring production. The manufacturer's response to this situation can be in the form of innovation and production of new types of flooring, combined with government measures to discourage the export of wood raw material and to build supply chains between small producers of raw material and high-value-added producers. This would contribute to strengthening the competitiveness of the wood flooring exporters.

\section{CONCLUSION}

\section{ZAKLJUČAK}

The research conducted and the results of the analyses in this paper have shown that the SEEC have a significant role in the production of wood flooring in Europe and their import into the EU. In 2018, 8.48 million $\mathrm{m}^{2}$ of wood flooring was produced in the SEEC, representing $9.4 \%$ of total production in Europe. 2.6 million $\mathrm{m}^{2}$ or $64 \%$ of total exports of wood flooring from this region were exported to the EU market. The share of exports from the region in the total EU imports of wood flooring in 2018 was $3.3 \%$, indicating that this market is important for exports and, therefore, for the production of wood flooring in the SEEC. This is confirmed by the results of econometric modelling, which shows that with every percentage increase in the EU imports, the production of wood flooring in the SEEC could be expected to increase by $0.75 \%$.

Concerning the competitiveness of the wood flooring exported from the region to the EU and other markets in the world, the conducted analyses and obtained values of the Competitiveness Growth Index (RCA1) have shown that the competitiveness of wood flooring in the region is satisfactory, especially in the segment of non-price elements of competitiveness. However, the analysis of price competitiveness has shown that the average values of wood flooring exports from the countries of the region are still lower than the average values of wood flooring imports of the selected EU countries. Therefore, it can be concluded that the raw material used in the production of wood flooring in the countries of the region has not yet reached the level of the added value that would be desirable in their export to the EU market. Therefore, the main competitive advantages of the SEEC continue to be in the area of lower export prices and lower operating costs of enterprises. For this reason, innovations are needed in the production of new types of flooring with significantly higher added value, in the short term.

\section{REFERENCES}

\section{LITERATURA}

1. Bobáková, V.; Hečková, J., 2007: Analýza konkurencieschopnosti slovenského spracovatel'ského priemyslu. Politická ekonómie, IV (4): 490-507.

http://dx.doi.org/10.18267/j.polek.610.

2. Dzian, M.; Paluš, H.; Parobek, J.; Šupín, M., 2018: Factors affecting the supply of energy wood in Slovakia: Proceedings of the 11th International Scientific Conference WoodEMA 2018: Increasing the use of wood in the global Bio-economy. WoodEMA and University of Belgrade-Faculty of Forestry, Belgrade, Serbia, pp. 347-353. http://www.woodema.org/conferences/2018_Beograd_ presentations/407_Dzian.pdf.

3. Glavonjić, B.; Baron, J.; Dundjerović, T.; PavlovićKrižanić, T., 2016: National action plan for supporting export of the high added value products of the Serbian wood industry, The United States Agency for International Development (USAID), the European Union and the Government of Switzerland, Published by UNOPS. http://www.europeanprogres.org/dokumenti/48_ 494580_wodworksactionplan.pdf.

4. Gravelsins, A.; Blumberga, A.; Blumberga, D.; Muizniece, I., 2017: Economic analysis of wood products: system dynamics approach. Energy Procedia, 128: 431-436. https://doi.org/10.1016/j.egypro.2017.09.023.

5. Hetemäki, L.; Hurmekoski, E., 2016: Forest Products Markets under Change: Review and Research Implications. Current Forestry Reports, 2 (3): 177-188. https://doi.org/10.1007/s40725-016-0042-z.

6. Jovičić, M.; Dragutinović-Mitrović, R., 2018: Ekonometrijski metodi i modeli. Ekonomski fakultet. Beograd, Srbija.

7. Milićević, S.; Nikolić M.; Cvetanović, S., 2017: The Competitivenes of Wood Processing Industry in the Republic of Serbia During The Period 1995-2015. Industrija 45 (3): 131-150. https://doi.org/10.5937/industrija45-14579.

8. Paluš, H.; Parobek, J.; Liker, B., 2015: Trade Performance and Competitiveness of the Slovak Wood Processing Industry within the Visegrad Group Countries. Drvna industrija, 66 (3): 195-201.

https://doi.org/10.5552/drind.2015.1431.

9. Parobek, J.; Paluš, H.; Kalamarova, M.; Loučanova, E.; Križanova, A.; Štofkova-Repkova, K., 2016: Comparative analysis of wood and semi-finished wood product trade of Slovakia and its Central European trading partners. Drewno, 59 (196): 183-194. https://doi.org/10.12841/wood.1644-3985.143.15.

10. Ranković, N., 1996: Ekonomika šumarstva. Šumarski fakultet. Beograd, Srbija.

11. Toppinen, A.; Kuuluvainen, J., 2010: Forest sector modelling in Europe-the state of the art and future research directions. Forest Policy and Economics, 12 (1): 2-8. https://doi.org/10.1016/j.forpol.2009.09.017.

12. ***: Data from the University of Belgrade Faculty of Forestry, Timber Trade Centre database (internal database). Belgrade, Serbia.

13. ***2019: "EUROSTAT Statistics Database. European Commission" (online). http://epp.eurostat.ec.europa.eu/ (Accessed September 12, 2019).

14. ***2019: "FEP (European Federation of the Parquet Industry), press releases for different years" (online). http:// www.parquet.net/nl/press/press-releases/ (Accessed September 5, 2019).

15. ***2019: "Croatian Bureau of Statistics" (online). https://www.dzs.hr/ (Accessed September 10, 2019). 
16. ***2019: "Statistical office of the Republic of Serbia" (online). http://www.stat.gov.rs/en-US/ (Accessed September 10, 2019).

17. ***2019: "Statistical office of the Republic of Slovenia" (online). https://www.stat.si/StatWeb/en/ (Accessed September 10, 2019).

18. ***2019: "Statistical office of Montenegro (MONSTAT)" (online).

https://www.monstat.org/eng/index.php/ (Accessed September 10, 2019).

19. ***2019: "State Statistical office of the Republic of North Macedonia" (online).

http://www.stat.gov.mk/Default_en.aspx/ (Accessed September 10, 2019).

20. ***2019: "Institute of Statistics of Albania" (online). http://www.instat.gov.al/en/Home.aspx/ (Accessed September 10, 2019).
21. ***2019: "The Agency for statistics of Bosnia and Herzegovina" (online).

http://www.bhas.ba/index.php?lang=en/ (Accessed September 10, 2019).

\section{Corresponding address:}

Prof. BRANKO GLAVONJIĆ, PhD.

University of Belgrade, Faculty of Forestry Department of Wood Science and Technology

Kneza Višeslava 1

11030 Belgrade, REPUBLIC OF SERBIA

e-mail: branko.glavonjic@sfb.bg.ac.rs 